\title{
GAYA BELAJAR AURAL PLAY DI YAMAHA MUSIK PADANG
}

\author{
Wahyu Eka Saputra ${ }^{*}$, Agusti Efi ${ }^{* *}$ \\ Program Studi Pendidikan Ilmu Pengetahuan Sosial Konsentrasi Pendidikan Seni dan Budaya \\ Program Pascasarjana \\ Universitas Negeri Padang \\ Jl. Prof. Dr. Hamta, Air Tawar Padang, Kel. Air Tawar Barat, Kec. Padang Utara, Kota Padang, Kode Pos 25171 \\ Sumatera Barat. Indonesia \\ Email: usaputra12@gmail.com
}

\begin{abstract}
Abstrak
Penelitian ini bertujuan untuk mengetahui pelaksanaan pembelajaran gaya belajar aural play di Yamaha musik Padang. Metode yang digunakan dalam mengetahui pelaksanaan pembelajaran aural play di Yamaha musik Padang ini adalah metode kualitatif natural observasi, dimana peneliti sebagai instrument utama penelitian. Siswa Yamaha musik padang memiliki kecendrungan menggunakan indra pendengaran untuk belajar dan mempraktekkan alat musik dengan menirukan kembali apa saja yang dilakukan oleh guru mereka. Walaupun telah adanya buku penunjang berisi notasi musik yang dipelajari dengan cara membaca, siswa lebih senang mendengarkan dan menirukan cara guru mereka mempraktekan materi musik yang sedang dipelajarinya. Oleh sebab itu perlu untuk dicari tahu kenapa siswa Yamaha musik padang sangat cendrung menggunakan gaya belajar aural play dalam mempelajari dan mempraktekkan instrument musik mereka. Penelitian ini diharapkan dapat menambah wawasan kajian pembelajaran musik tentang penerapan gaya belajar aural kepada siswa di lembaga pendidikan musik, mampu memperkaya teori tentang gaya belajar aural dan terhadap pengembangan ilmu pengetahuan yang berkaitan dengan gaya belajar aural.
\end{abstract}

Kata Kunci: gaya belajar, musik, aural, play.

\begin{abstract}
This research study is to study the implementation of aural play style learning in Yamaha Padang music. The method used in studying the implementation of learning to play in Yamaha Padang music is a qualitative method of natural observation, where the researcher as the main research instrument. Yamaha Padang students have a tendency to use the sense of hearing to learn and practice musical instruments by imitating whatever their teacher does. Although there are supporting books containing music notation that are learned by reading, students prefer to listen and imitate the way their teacher practices the music material that they are learning. Therefore it is necessary to know why Yamaha Padang students are so inclined to use aural learning learning styles in discussions and practice their musical instruments. This research is expected to add insight into music learning about the application of aural learning styles to students in music education institutions, able to enrich theories about aural learning styles and to the development of knowledge related to aural learning styles.
\end{abstract}

Keywords: learning style, music, aural, play.

\section{PENDAHULUAN}

Yamaha musik adalah salah satu dari sekian lembaga musik non formal yang ada di Indonesia yang menyediakan sarana prasarana untuk melaksanakan proses pembelajaran musik untuk siswa-siswi yang masih dalam bangku pendidikan maupun non kependidikan. Keberadaan Yamaha musik sudah tersebar luas di berbagai penjuru daerah Indonesia, salah satunya adalah di Sumatera barat yaitu di kota Padang yang beralamat di Jl. Pemuda, Olo, Kec. Padang Barat Kota Padang, Sumatera Barat. Di Yamaha musik Padang telah membuka berbagai fokus praktek instrument musik pembelajaran yaitu ; vocal, biola, drum, gitar, piano dan keyboard. Selain itu,
Yamaha musik padang memakai standar pembelajaran maupun silabus yang telah disusun oleh penyusun kurikulum Yamaha musik Jepang.

Penulis melatar belakangi suatu pemahaman tentang gaya belajar musik menggunakan aural play di Yamaha musik padang. Penulis mengamati secara mendasar pada saat paraktek belajar musik yang dilakukan di Yamaha musik Padang, dimana secara umum Siswa Yamaha musik padang memiliki kecendrungan menggunakan kepekaan pendengaran kemudian menirukan kembali dari pengajarnya untuk mempraktekkan sebuah repertoar lagu. Walaupun menggunakan buku penunjang dari kurikulum Yamaha 


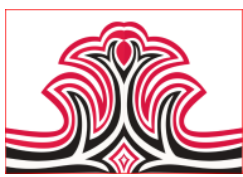

musik yang didalamnya terdapat notasi musik dari kumpulan repertoar lagu, tetap saja siswa lebih cendrung mendengarkan apa yang dimainkan oleh gurunya disaat kelas musik berlangsung kemudian menirukannya kembali dengan memainkannya. Berdasarkan pengamatan ini semua, hal ini perlu di kaji untuk lebih mendalam lagi bagaimana siswa Yamaha musik padang memiliki kecendrungan belajar musik dengan gaya belajar aural play.

\section{KAJIAN TEORI}

Musik dapat dipelajari dan dikembangkan melalui proses pembelajaran seperti yang ada pada kurikulum pendidikan sekolah maupun lembaga pendidikan non formal lainnya. Di sekolah, musik termasuk pada bagian mata pelajaran seni budaya (Suharto, S, 2007). Begitu juga pada lembaga non formal seperti tempat kursus musik, yang membentuk setiap siswa untuk mahir dalam memainkan alat musik.

Didalam belajar musik, terdapat berbagai unsur yang menjadi potensi dasar yaitu bakat, metode belajar, paraktek dan alur belajar yang tepat, ( Ghozali, I , 2011). Penulis berpendapat ke-empat unsur ini akan menjadi kunci kesuksesan jika setiap individu yang belajar musik diperhatikan dengan cermat. Pembelajaran musik merupakan suatu proses pemahaman baik secara keilmuan teori maupun prakteknya kedalam bentuk bermain musik. Didalam proses pembelajaran musik, siswa dituntut untuk mampu menguasai teori dan paraktek kemudian berkreasi sendiri terhadap praktek yang telah di laksanakan (Subandi, et al, 2017).

Terdapat tiga gaya belajar musik untuk mempelajarinya secara umum. Ketiga gaya tersebut adalah mendengar, membaca dan menirukan. Gaya belajar dengan cara mendengarkan disebut dengan “Auditory learner"atau disingkat dengan istilah "Aural". Biasanya, siswa dengan gaya belajar aural cendrung mendengarkan audio, ceramah dalam pembelajaran, mendengarkan diskusi maupun debat, dan instruksi verbal. Demi mendapatkan kesuksesannya dalam hal belajar, siswa yang cenderung memiliki gaya belajar seperti ini akan memanfaatkan indra pendengarannya untuk mengolah informasi dari pembelajaran yang sedang dilaksanakannya (Waluyo, M. E., 2014). Didalam belajar musik, siswa yang memiliki gaya belajar aural akan memiliki kemudahan untuk mengenal nada, ritem, harmoni, dinamika dan unsur musik lainnya sehingga siswa tersebut tidak akan sulit jika melaksanakan pembelajaran musik
Gorga Jurnal Seni Rupa

Volume 08 Nomor 02 Juli-Desember 2019 p-ISSN: 2301-5942 | e-ISSN: 2580-2380

Gaya belajar yang kedua dalam proses pembelajaran musik adalah membaca notasi. Membaca notasi adalah proses untuk memainkan sebuah repertoar lagu atau ritem dengan melihat notasi musik yang telah tertulis di kertas. sebelum membaca notasi musik ini, seseorang harus menguasai ilmu solfegio. Solfegio adalah ilmu membaca ritem didalam musik.Solfegio adalah istilah yang mengacu pada menyanyikan tangga nada, interval dan latihan-latihan melodi dengan sillaby zolmization, yaitu menyanyikan nada musik dengan menggunakan suku kata, (Mumpuni, 2007; Stanly, 1980; Sumaryanto, 1997). Siswa yang telah menguasai ilmu solfegio ini, akan memiliki kemudahan dalam belajar musik dengan cara membaca notasi.

Gaya belajar musik yang ketiga yaitu dengan cara meniru, pemandu "guide" bisa juga meniru dari video musik yang ada di internet seperti Youtube atau menirukan seorang guru yang sedang mempraktekkannya.Seperti contoh, didalam belajar praktek musik, biasanya siswa di perintahkan untuk mengikuti setiap langkah yang dilakukan oleh pengajar. Misalnya pengajar melafal kan sebuah nada atau ritem, maka siswa langsung menriukan yang di lafalkan pengajar.

\section{METODE PENELITIAN}

Metode penelitian yang digunakan dalam mengidentifikasi gaya belajar aural play di Yamaha musik Padang ini adalah natural observasi. observasi adalah dasar yang sangad fundamental dari semua bentuk data data yang akan dikumpul pada penelitian kualitatif. Menurut Werner dan schoepfle (1987:257), disebutkan bahwa observasi adalah mengamati dengan sistematis dari objek penelitian secara fisik yang berlangsung secara terus menerus untuk menghasilkan aktifitas yang alami dali objek yang diteliti . Sedangkan menurut adi (1986 : 32) mengatakan observasi adalah sebagai suatu proses yang kompleks tersusun sebagai proses biologis maupun psikologis yang melibatkan pengamatan, persepsi dan ingatan, (Hasanah, H. , 2017). Dengan metode natural observasi, peneliti akan mengamati dan memahami penerapan belajar musik menggunakan gaya aural di Yamaha musik padang.

\section{HASIL DAN PEMBAHASAN 1.Hasil}

Dalam pelaksanaan menggunakan gaya belajar aur1al di Yamaha musik padang, guru-guru melakukan langkah belajar dengan memperdengarkan rekaman musik audio pelajaran kemudian mempraktekkan lagu tersebut dan ditirukan oleh siswa maupun siswi Yamaha musik Padang. Hal ini terus berlanjut sampai lagu tersebut dibahas hingga selesai. Kemudian guru 
mencontohkan lagu dengan mempraktekkan secara utuh, supaya siswa melihat dan mendengarkannya dengan seksama. Pada tahap akhir barulah siswa menirukan kembali yang telah dipraktekkan guru dari awal lagu sampai selesai.

\section{Pembahasan}

Gaya belajar adalah karakteristik dari kognitif afektif maupun psikomotorik yang merupakan pemicu utama dalam menerima suatu informasi dari pelajaran yang sedang diterima, (Sinaga, R. F.,2016). Setelah melakukan riset observasi di Yamaha musik padang, sebagian besar siswa-siswi yang belajar musik di Yamaha musik padang cendrung menggunakan gaya belajar Aural play yaitu dengan cara mendengarkan bagaimana guru mereka mempraktekkan permainan musik kemudian ditirukan kembali oleh siswa mereka.

Hal ini penulis temukan pada saat siswa yang sedang belajar dibidang studi keahlian alat musik biola. Pada saat membahas materi ajar menggunakan buku pelajaran biola yang didalamnya terdapat notasi dari berbagai lagu, siswa dituntut untuk mampu membaca notasi dari buku tersebut. Walaupun secara mendasar telah diajarkan terlebih dahulu bagaimana cara membaca notasi musik, tetapi siswa siswi tetap saja melihat bagaimana guru meraka mencontohkan bunyi melodi lagu musik yang dipelajari di buku tersebut. Setelah guru selesai mencontohkannya, siswa baru mengerti dan paham serta langsung mempraktekkan lagu tersebut dengan biolanya.

Pada bidang studi lain seperti bidang studi Vokal, hasil pengamatan penulis bahwa siswa siswi vocal lebih cendrung mengikuti gaya bernyanyi dari guru mereka dari pada membaca notasi yang ada di buku pelajaran. Guru vocal mencontohkan teknik bernanyi dimulai dari pola ritem, dinamik serta improvisasi vocal jika dibutuhkan, setelah itu siswa menirukan apa yang telah dicontohkan oleh guru mereka. Hal ini terbukti lebih efektif karena siswa mampu belajar dengan cepat daripada membaca buku notasi, kata guru vocal pada saat dilakukan wawancara singkat.

Bukan hanya itu saja, hal seperti ini juga terjadi pada bidang studi piano dan drum. Siswa juga menirukan apa yang dicontohkan oleh guru mereka, kemudian memainkannya. Walaupun telah ada bentuk permainan musik tersebut di partitur musik yang ada di buku pelajaran masing-masing bidang studi, tetapi tetap saja siswa mengalami kesulitan dalam membaca dan lebih suka melihat serta mendengarkan guru mereka mencontohkan musiknya terlebih dahulu dari buku pelajaran, kemudian barulah mereka paham dan memainkan sesuai dengan contoh yang telah dilihat maupun didengar dari gurunya

Dari hasil penjabaran diatas merupakan hasil observasi penulis secara natural. Sebagian besar siswa-siswi Yamaha musik padang cendrung mendengarkan guru mereka mempraktekkan musik terlebih dahulu dan kemudian diikuti oleh siswa mereka. Siswa juga telah diajarkan cara membaca notasi musik sesuai dengan bidang studi mereka masing-masing. Tetapi tetap saja sebagian besar siswa-siswi Yamaha musik Padang lebih cenderung mendengarkan guru mereka terlebih dahulu.

\section{KESIMPULA DAN SARAN}

\section{Kesimpulan}

Gaya belajar adalah kecendrungan tertentu yang dimiliki oleh setiap orang dalam menerima pelajaran. Setiap orang memiliki karakteristik afektif, psikomotorik maupun kognitif yang berbeda-beda. Dengan karekteristik yang berbeda ini setiap orang juga memiliki cara tersendiri dalam menerima informasi pelajaran yang diberikan oleh pengajarnya. Salah satunya pada bidang musik dimana gaya belajar menjadi penentu suksesnya seseorang dalam mempelajarinya. Seperti yang ada di Yamaha musik padang yang merupakan sekolah musik non formal. Di Yamaha musik padang memiliki kurikulum pelajaran tersendiri yang telah disusun oleh tim kurikulum Yamaha musik. setiap bidang studi memiliki buku pelajaran. Guru- guru telah dilatih untuk memberikan pengajaran sesuai dengan kurikulum belajar Yamaha musik.

Dalam memberikan pembelajaran kepada siswa-siswi, pengajar di Yamaha musik Padang menerapkan cara belajar dengan gaya belajar aural play. Karena sebagian besar siswa-siswi lebih cendrung menggunakan pendengarannya dalam menerima pelajaran yang diberikan. Sesuai dengan pencapaian yang ada di buku pelajaran, guru mengajarkan musik kepada siswa-siswi secara perlahan hingga selesai dengan cara mendengarkan audio berulang-ulang dan mempraktekkanya kemudian ditirukan oleh siswa bidang studi musik masing-masing. Setelah pembahasan selesai guru mempraktekkan lagu yang dipelajari oleh siswa secara utuh, dan terakir praktekkan kembali oleh siswa. Begitulah bentuk pelaksanaan pembelajaran musik dengan gaya belajar aural play, dimana dengan cara seperti ini siswa lebih cepat memahami dan berproses dalam mempelajari praktek instrument musik.

\section{Saran}

Pembelajaran menggunakan gaya aural dalam belajar 
musik memang baik, karena dapat meningkatkan sensitifitas pendengaran dan meningkat kan rasa musikalitas individu seseorang. Diharapkan agar dampak baik dari penggunaan metode belajar musik yang menggunakan gaya aural ini lebih diterapkan untuk lebih luas lagi dan semoga dengan pembahasan tentang gaya belajar aural play ini menjadi referensi untuk peneliti selanjutnya sebagai acuan dalam meneliti gaya belajar yang baik dalam musik.

\section{DAFTAR RUJUKAN}

Ghozali, I. (2011). Pembelajaran Musik Berbasis Siswa dengan Pendekatan Local Genius. Jurnal Visi Ilmu Pendidikan, 7(1),

Jatmiko, O. B. (2016). Teori Musik I: Musik Tonal.

Mudjilah, H.S. (2004). Teori Musik I: Yogyakarta: Banoe, Pono. (2003). Kamus Musik. Yogyakarta: Universitas Negeri Yogyakarta Fakultas Bahasa dan Seni.

Mumpuni, H.S. (2007). Metode Solfegio di Kelas IV

Unggulan Sekolah Dasar Negeri Ungaran Kaupaten Semarang. Semarang: UNNES.

Sinaga, R.F. (2016). Pengaruh Model Pembelajaran dan Gaya Belajar Terhadap Hasil Belajar IPA. Medan: Doctoral Dissertation UNIMED.

Suharto, S. (2007). Pengembangan Materi dan Kegiatan Pebelajarannya dalam Kurikulum Tingkat Satuan Pendidikan Bidang Seni. Harmonia: Journal of Arts Research and Education, 8(3),

Subandi, D., Julia, J., \& Gusrayani, D. (2017). Strategi Pembelajaran Musik Ensemble Melalui Media Gamelan Degung pada Siswa Kelas V Sekolah Dasar. Jurnal Pena Ilmiah, 2(1), 209230.

Waluyo, M.E. (2014). Revolusi Gaya untuk Fungsi. Otak Nadwa, 8(2), 209-228. 